\title{
Study the Viability of Some Bacterial Species Isolated from Contaminated Soils on the Manufacture of Nanoparticles
}

\author{
Eman MohammadTaher, Dalia Abdulelah Mohammad, NajlaAhmad Suleiman \\ University of Mosul /college of science/department of biology
}

\begin{abstract}
Researchers in nanoparticle manufacturing have recently turned to biomanufacturing to reduce silver ions into silver nanoparticles because these microorganisms work as ecofriendly nanofactories, which were controlled on the size and shape of manufactured nanoparticles, this technique can occur either inter the cellular structure or extracellular structure, but the extracellular synthesis is cheaper and require simple processing technique .Therefore, in the current study bacterial strains isolated from contaminated soil with motor oil were selected to synthesize silver nanoparticles by extracellular method at $37 \mathrm{C}^{\circ}$ for $(72-168)$ hours. The result of fabrication was observed by the shift in thecolor of reacted solution into yellowish brown and confirmed the fabrication of Ag NPs by UV-Visible spectroscopy that measured the absorption spectra of Ag NPs which was located between (404 -444) nm. Also,FITR analysis was used to determine the functional groups of bacteria that participated in the reduction of $\mathrm{Ag}^{+}$into Ago through notice the presence of band located between (3344-3310) $\mathrm{cm}^{-1}$ related to $\mathrm{NH}$ (Amide) and the presence of bandbetween(1633-1636) $\mathrm{cm}^{-1}$ assigned to $\mathrm{C}=\mathrm{O}$ (carbonyl amide). Finally, AgNPs fabricated by supernatant of Bacillus strains when reacted with $3 \mathrm{mM} \mathrm{AgNO} 3$ solution showed more effective against Staphylococcus aureus than E. coli.
\end{abstract}

Keyword: Biosynthesis of Ag NPs, Bacillus spp., UV-Visible Spectroscopy ,FITR ,Antibacterial Activity. DOI : doi.org/10.46617/icbe6002

\section{Introduction:}

One of the most important fields for researches in nanotechnology is biosynthesis of metal nanoparticles due to having numerous applications in various fields like therapeutics, bimolecular detection, catalysis $[1,2]$. Therefore, the studies in this fieldwere turned on to use biological approach because these nanofactories method have significant advantages compared toother process because these nanofactories have the ability to synthesize nanoparticles in an ecofriendly method [3] bacteria is the most favorable between microorganisms because it is relatively easy to handle and can produce bio component like enzymes, proteins and biosurfactant (lipopeptides), these biomolecules form bio-reducing agent by bacterial cell metabolic activities[4,5,6]. In many bacteria strains these biomolecules are used as capping agent which makes nanoparticles more stable. Bio reductionof silver ions by microorganism can occur by extracellular orintracellular[7].Extracellular manufacturing of nanoparticles happens by limitation metal on the surface of bacteria while intracellular manufacturing occurs inside bacteria and needs extra steps to obtain nanoparticles like treatment by ultrasound to release the synthesized silver nanoparticles.Many studies concentrated on Extracellular synthesis because of it is cheap, simple and provides large scale production[8,1].RecentresearchesreportedthesynthesisofAgNPsby Bacillus subtilis and Enterococcus spp., Morganella spp. [9,10,4]. Bacterial strains isolated from soil contaminated with hydrocarbons materials were tested for their strength to reduce $\mathrm{Ag}$ ions to $\mathrm{Ag}$ NPs, which identified biochemical and molecular by 16SrRNA as Gram-positive Bacilli bacterium forming spores related to genus Bacillus [11] 


\section{Material and methods:}

\subsection{Isolation and identification of bacteria from contaminated soil :}

$10 \mathrm{gm}$. of each soil sample contaminated with generator oils in Mosul was collected and taken from a depth of $5 \mathrm{~cm}$ using a sterile spatula and placed in sterile plastic bags, then transferred to the laboratory for making serial of ten dilution by adding it to $90 \mathrm{ml}$ of sterile D.W. to obtain the first dilution $10^{-1}[12]$. Then added $0.1 \mathrm{ml}$ of $10^{-4}, 10^{-5}$ dilution separately to sterile Petridis containing Nutrient Agar and incubated at $37 \mathrm{C}^{\circ}$ for 24 hours to obtain bacterial colonies that were subculture individually on N.A. for purification .Later bacterial isolates identified biochemically and molecularly based on 16srRNA gene sequence analysis described[13,14,15].

\subsection{Synthesis of silver nanoparticles:}

Some bacterial strains identificated by molecular and biochemical methods were selected to synthesize silver nanoparticles by inoculating it individually in $100 \mathrm{ml}$ of sterile N.B. media and incubated in incubator shaker rotate at $200 \mathrm{rpm}$ for 24 hours to obtain bacterial suspension with concentration $1.5 \times 10^{8}$ compared with McFarland tube $(0.5)$. Then added $50 \mathrm{ml}$ of a bacterial strain to flask containing $50 \mathrm{ml}$ of $1 \mathrm{mM}$ of $\mathrm{AgNO}_{3}$ solution and incubated in $150 \mathrm{rpm}$ for $72-168$ hours in dark condition.After that supernatant of the reaction mixture was separated by centrifuged it at speed $10000 \mathrm{rpm}$ for $10 \mathrm{~min}$. Finally, the pellet of Ag NPs was collected and stored for further usage $[13,16,17]$.

\subsection{Characterization of silver nanoparticles :}

The initial detection of Ag NPs was noted for color changing for solution resulting from the reaction to check the fabrication of nanoparticles by nanofactories through the extracellular method and analyzed optical characteristics of Ag NPs and scanned the absorption spectra between 200-900 $\mathrm{nm}$. Also, FITR were analyzed for the reaction mixture to investigate functional groups that participated to reduce $\mathrm{Ag}^{+}$into silver atom $\operatorname{Ag}^{0}[16,18]$.

\subsection{Antimicrobial Activity of Fabricated AgNPS:}

The antimicrobial activity of synthesized Ag NPs against some bacteria was investigated on Mueller-Hinton agar (M.H.A.) plates by using disk diffusion method. About $0.1 \mathrm{ml}$ of suspension for pathogenic bacteria like $E$. coli, and staphylococcus aureus at concentration $1.5 \times 10^{8}$ compared with McFarland tube after incubated it for 24 hours then was spread evenly on solid media of M.H.A. plate by sterile swabs. Later $20 \mu \mathrm{l}$ for the pellet of Ag NPs and $\mathrm{AgNO}_{3} \mathrm{at}(3 \mathrm{mM}$, $2 \mathrm{mM}$ ) concentration and supernatant of Bacillus strains was added separately to the wells which was made by Cork borer then incubated it at $37 \mathrm{C}^{\circ}$ for 24 hours.From the observation of inhibition zone appeared around the wells can determine antibacterial activity against pathogenic bacteria $[19,20]$.

\section{Results and Discussions}

\subsection{Identification of bacterial strains :}

The isolates bacteria from soil were identified biochemically as gram positive bacilli forming spore and by 16srRNA gene sequences showed that the isolates M1,M2 ,M3,M4, S10 were identified as Bacillus paramycoides,Bacillus subtilis, Bacillus paramycoides,Bacillus cereus, Bacillus wiedmanniiillustrated in the Table (1). 
Table (2) Diagnosis of bacterial isolates according to 16srRNA

\begin{tabular}{|c|l|c|c|}
\hline Number of strain & \multicolumn{1}{|c|}{ Name of strain } & DNA Extraction & $\begin{array}{c}\text { PCR Result16srRNA } \\
\mathbf{1 2 5 0} \text { bp }\end{array}$ \\
\hline M1 & Bacillus paramycoides & + & + \\
\hline M2 & Bacillus subtilis & + & + \\
\hline M3 & Bacillus paramycoides & + & + \\
\hline M4 & Bacillus cereus & + & + \\
\hline S10 & Bacillus wiedmannii & + & + \\
\hline
\end{tabular}

\subsection{Characterization of Fabricated Ag NPs:}

Formation of silver nanoparticles by supernatant of Bacillus strains when treated with a solution of $\mathrm{AgNO}_{3}$ was observed visually by the color shift of reaction mixture from pale yellowto yellowish brown at the end of incubation. Brown properties may be due to excitation of the Plasmon Surface Resonance (SPR) of the nanoparticles and were provided appropriate substantiates of their fabrication. These color changes were shown in Fig. [1]

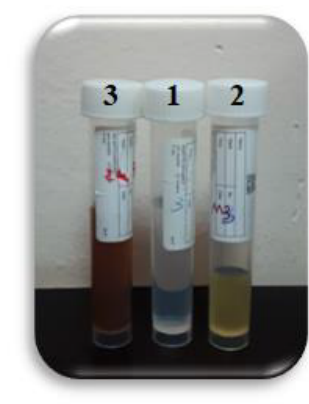

Bacillus paramycoides

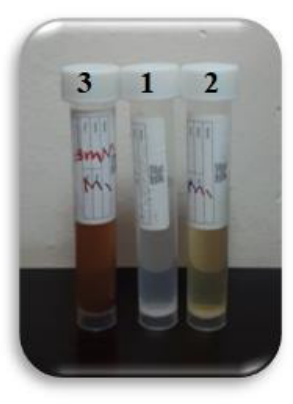

Bacillus paramycoides

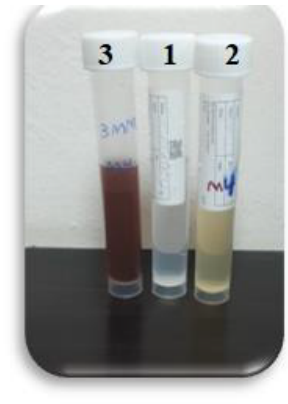

Bacillus cereus

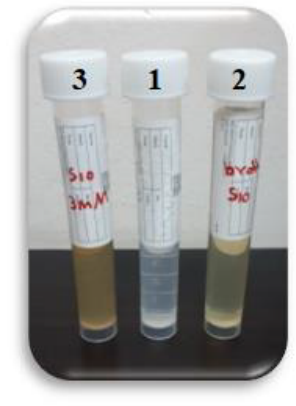

Bacillus wiedmanni

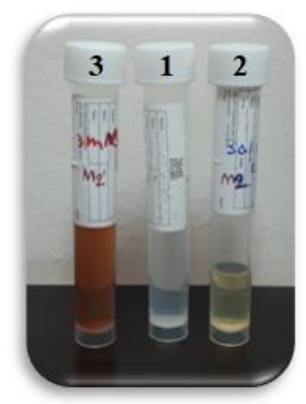

Bacillus subtilis

Figure (1) Visual observation of synthesized silver nanoparticles by supernatant of bacterial strains(1)(Control) $\mathrm{AgNO}_{3}$ solution(2)supernatant of bacteria(3)Ag NPs solution

There was evidence that an electron shuttle or other reducing agents were released into the culture of Bacillus spp. and participated in bioreduction of silver ions $\mathrm{Ag}^{+}$into silver atom $[21,22]$.By measurement of UV_Visible spectroscopy can be observed a absorption peak located between(404-444)nm suggest the presence of Surface Plasmon Resonance which is properties of silver nanoparticles that prepared using culture supernatant of selectedstrains used in this study 
like Bacillus wiedmannii, Bacillus paramycoids, Bacillus subtilis, Bacillus paramycoids was concentrated at $(404,424,438,444) n m$ respectivelyand illustratedin Fig.(2)similar observation was previously reported by $[9,19,23]$.

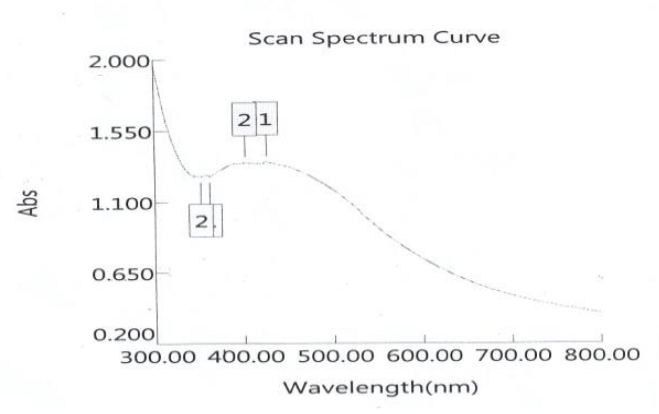

Bacillus paramycoids

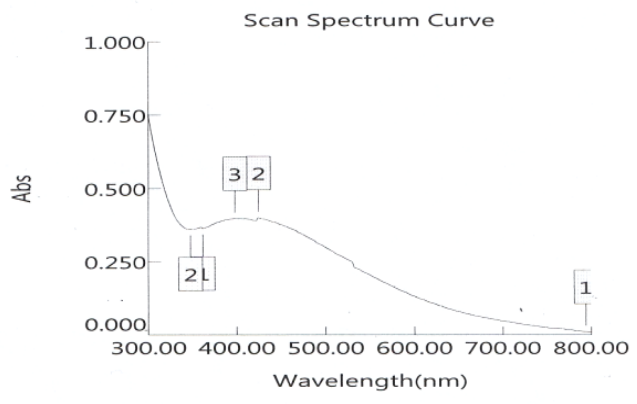

Bacillus paramycoids

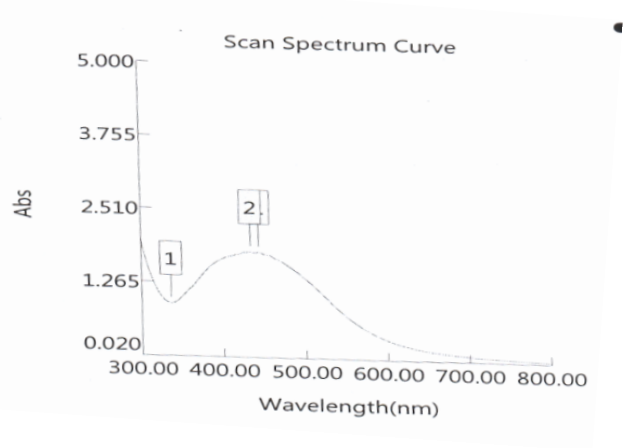

Bacillus subtilis

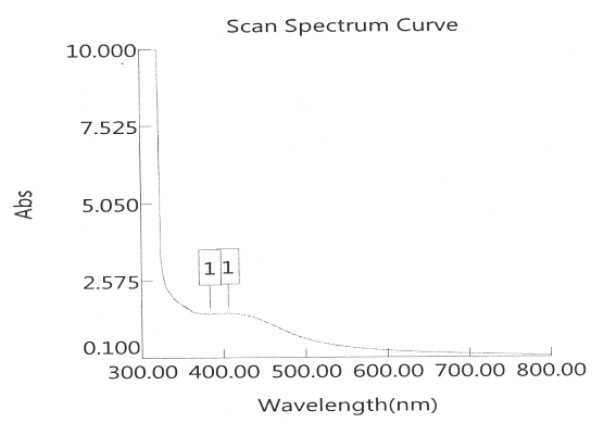

Bacilluswiedmannii

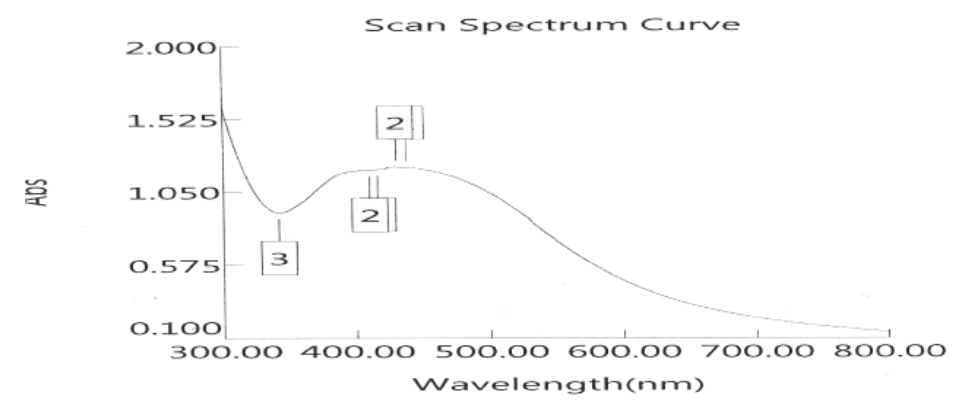

Bacillus cereus

Figure (2) Show UV-Visible absorption beak of Ag NPS synthesized by supernatant of Bacillus SPP.

\subsection{FITR analysis :}


measurement of FITR for solution Ag NPs showed the presence of bands located at region between (33310-3344) $\mathrm{cm}^{-1}$ were possibly related to $\mathrm{NH}$ ( amide ) that confirm presence of protein in the sampleand corresponding with previously studies [9,19,23].Also presence of band located between (2190-2281) $\mathrm{cm}^{-1}$ assigned to $\mathrm{C}=\mathrm{N}(\mathrm{Nitrile})$ and the appearance of band at (16331634-1635-1636) $\mathrm{cm}^{-1}$ assigned to $\mathrm{C}=\mathrm{O}$ (carbonyl amide).all bands illustrated in Fig (3)

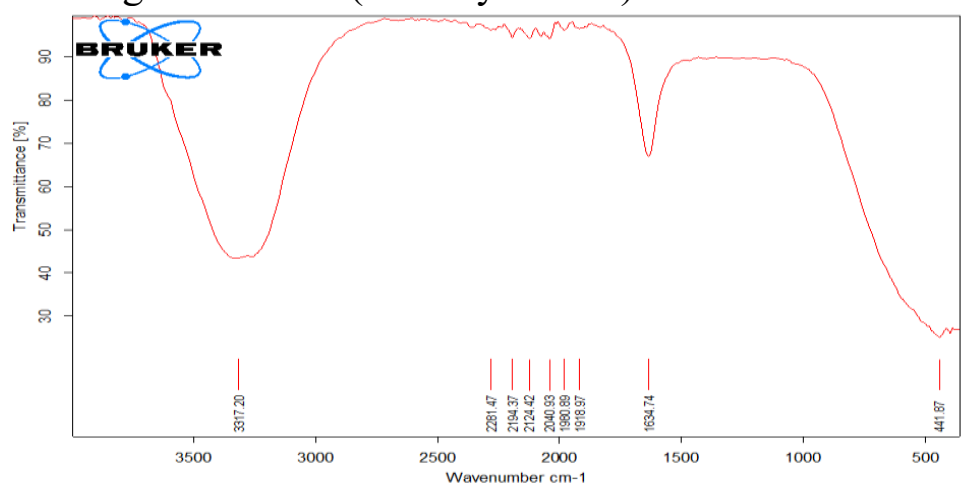

Bacillus paramycoids

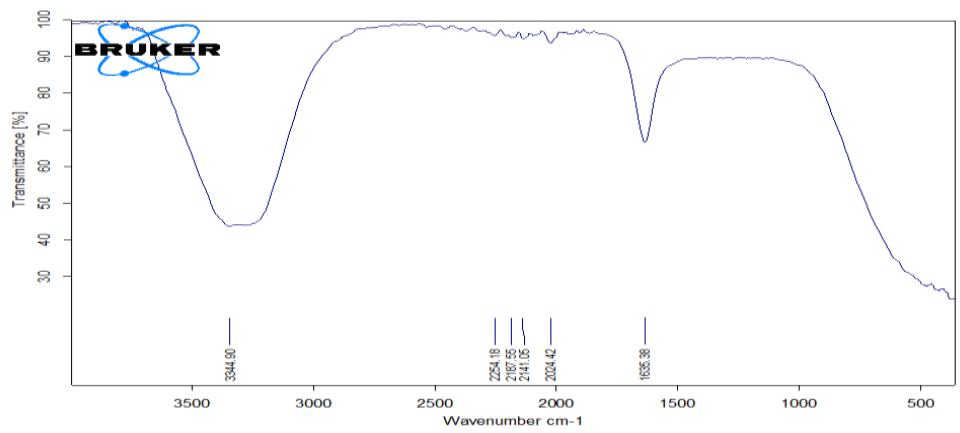

Bacillus subtilis

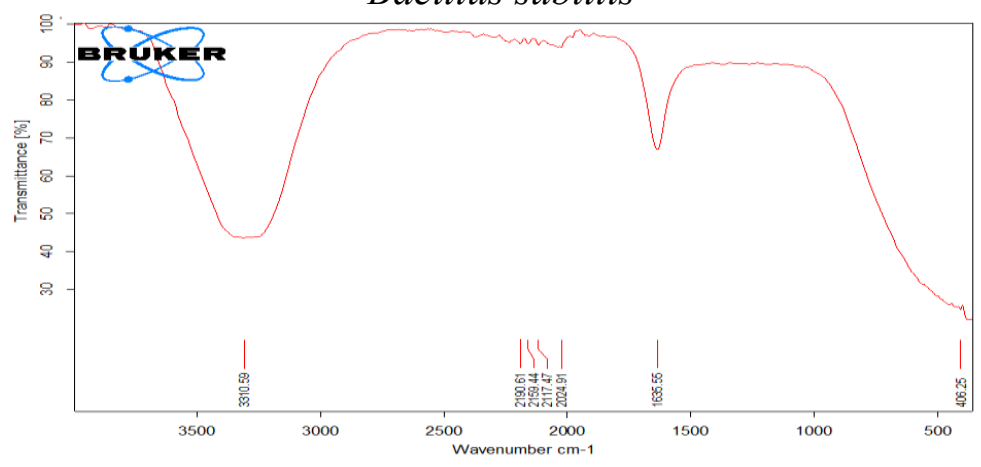

Bacillus paramycoids 


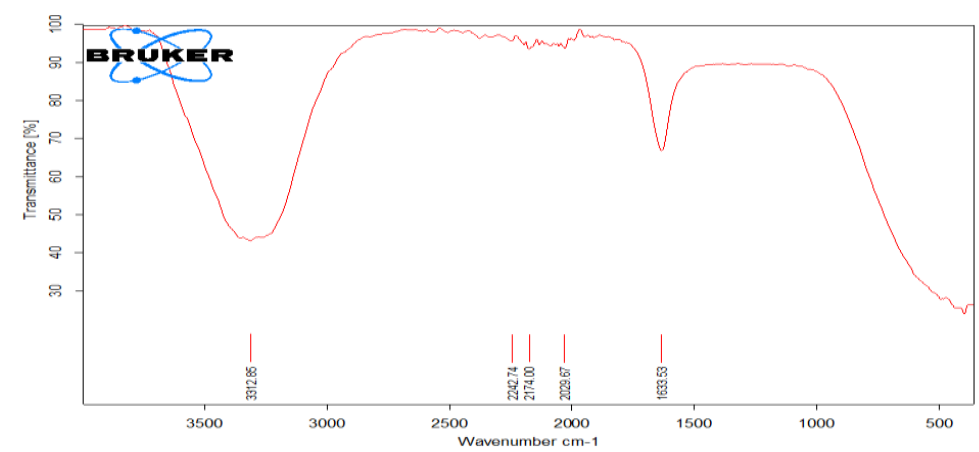

Bacillus cereus

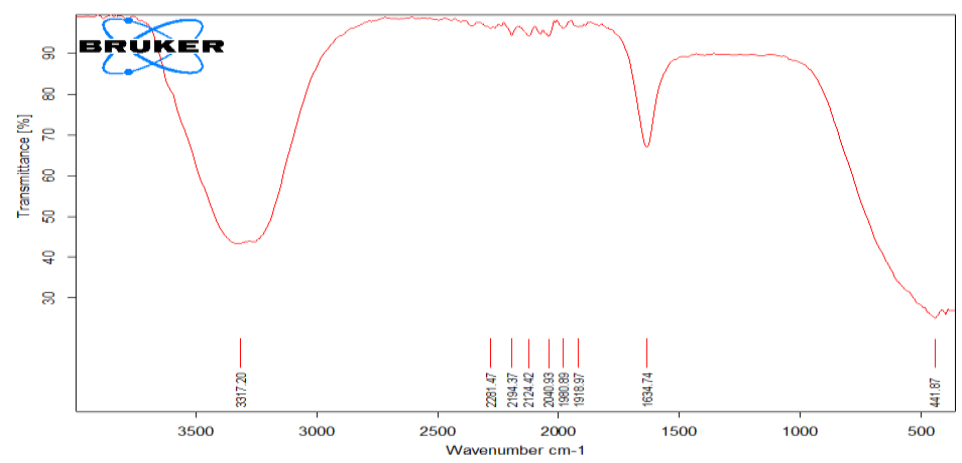

Bacilluswiedmannii

Figure (3) FITR analysis of Ag NPs fabricated by supernatant of Bacillus strains

\subsection{Antibacterial Effectiveness of AgNPs:}

The synthesized Ag NPs by supernatant of Bacillus subtilis Bacillus cereusBacillus wiedmannii, which incubated with $3 \mathrm{mM} \mathrm{AgNO}_{3}$ solution showed the highest antimicrobial efficiency against staphylococcus aureuscomparison to $E$. coli the reason may be due the plasmolysis of the cell wall and separate cytoplasm from it, the mechanism of antibacterial activity of bio silver was differ from species to another and depending on the size of nanoparticles .this result was in agreement with previously studies by $[19,24]$. The activity of Ag NPs was illustrated in Table(2)

Table (2) Antibacterial activity of Ag NPs synthesized by supernatant of Bcillus strains

\begin{tabular}{|l|l|c|c|c|c|c|c|c|}
\hline $\begin{array}{c}\text { Tested } \\
\text { Bacterial } \\
\text { strain }\end{array}$ & Type of bacillus & $\begin{array}{c}\mathrm{AgNO}_{3} \\
\mathbf{3 m M}\end{array}$ & $\begin{array}{c}\mathrm{AgNO}_{3} \\
\mathbf{2 m M}\end{array}$ & $\begin{array}{c}\text { suspension } \\
\text { of bacteria }\end{array}$ & $\begin{array}{c}\text { sediment } \\
3 \mathrm{mM}\end{array}$ & $\begin{array}{c}\text { Sediment } \\
2 \mathrm{mM}\end{array}$ & $\begin{array}{c}\text { Filtrate } \\
3 \mathrm{mM}\end{array}$ & $\begin{array}{c}\text { Filtrate } \\
2 \mathrm{mM}\end{array}$ \\
\hline \multirow{2}{*}{$\begin{array}{l}\text { Staph. } \\
\text { aureus }\end{array}$} & $\begin{array}{l}\text { Bacillus } \\
\text { paramycoid }\end{array}$ & 15 & 12 & 6 & 21 & 15 & 14 & 13 \\
\cline { 2 - 9 } & Bacillus subtilis & 26 & 26 & 6 & 29 & 32 & 14 & 12 \\
\hline
\end{tabular}


Proceeding of $6^{\text {th }}$ nternational Conference of Biotechnology, Environment and Engineering Sciences (ICBEI) 28 - 29 December 2019, Alexandria-Egypt

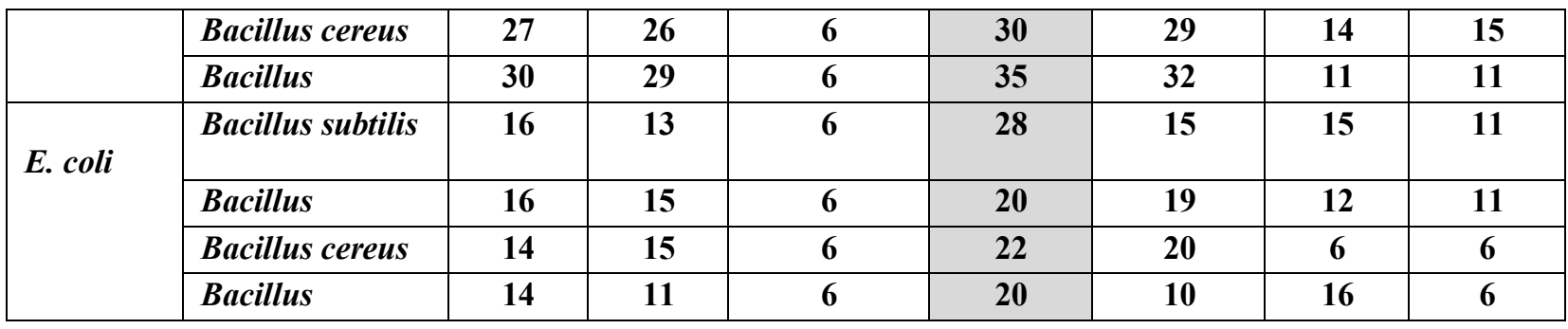

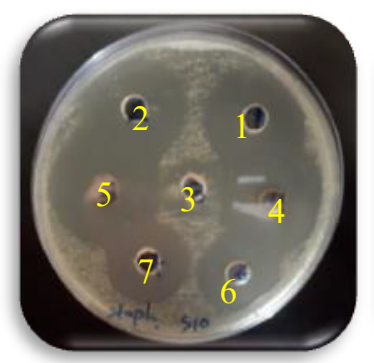

Bacillus wiedmanniiBacillus subtilis

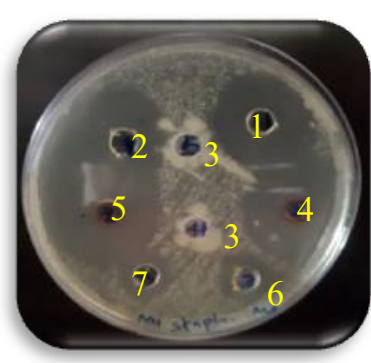

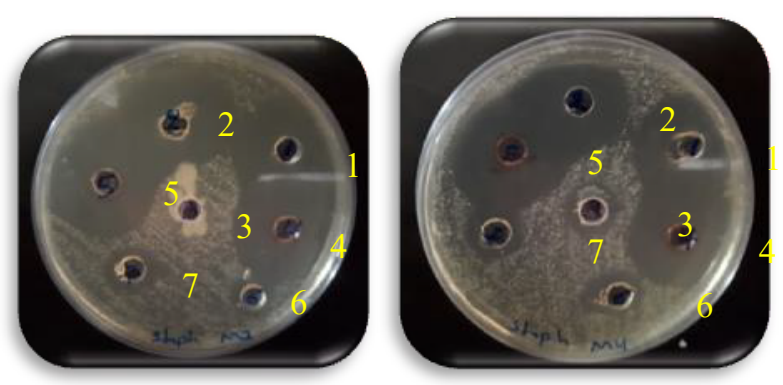

Bacillus paramycoidBacillus cereus

\section{Antimicrobial activity of Ag NPssynthesized by supernatant of BacillusSPP.against staphylococcus aureus}

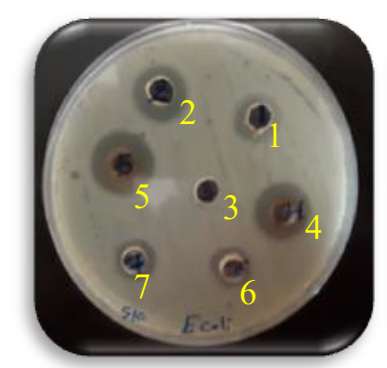

Bacillus wiedmanniiBacillus subtilis
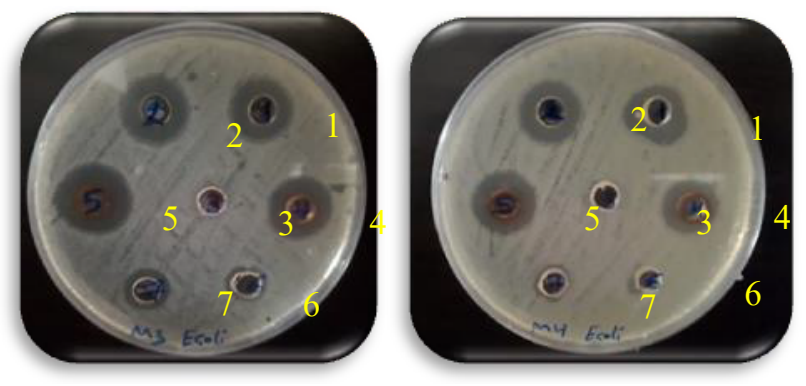

Bacillus paramycoidBacillus cereus

Figure (3) Illustating antimicrobial activity of Ag NPssynthesized by supernatant of BacillusSPP.against E.coli

(1) $2 \mathrm{mM} \mathrm{AgNO}_{3}$ solution (2) $3 \mathrm{mM} \mathrm{AgNO}_{3}$ solution (3)supernatant of bacteria(4)sediment of $2 \mathrm{mM}$ AgNPS(5) sediment of $3 \mathrm{mM}$ AgNPs (6)filtrate of $2 \mathrm{mM} \mathrm{AgNPs}(7)$ filtrate of $3 \mathrm{mM}$ of AgNPs

\section{Conclusion:}

We conclude from the present study the possibility of bacteria isolated from soil contaminated with motor oils to reduce silver ions to silver atoms by producing them for some effective compounds such as proteins and enzymes to form nanoparticles that is showed more effective against staphylococcus aureus than E. coli when the bacterial supernatant of some Bacillus strains reacted with $3 \mathrm{mM} \mathrm{AgNO}$.

\section{Reference:}

[1] Duran, N., Priscyla, D., Marcato, P.D., Alves, O., De Souza, G. and Esposito, E., 2005. Mechanistic aspects of biosynthesis of silver nanoparticles by several Fusariumoxysporum strains. $J$ Nanobiotechnol,3,1-7. 


\section{Proceeding of $6^{\text {th }}$ nternational Conference of Biotechnology, Environment and Engineering Sciences (ICBEI) 28 - 29 December 2019, Alexandria-Egypt}

[2] Christopher, P., Xin, H. and Linic, S., 2011.Visible-light-enhanced catalytic oxidation reactions on plasmonic silver nanostructures. NatChem, 3,467-472.

[3]Wei, X., Luo, M., Li, W., Yang, L., Liang, X., Xu, L., Kong, P. and Liu, H., 2012. Synthesis of silver nanoparticles by solar irradiation of cell-free Bacillus amyloliquefaciens extracts and $\mathrm{AgNO}_{3}$.BioresourTechnol ,103,273-278.

[4] Parikh, R.Y., Singh, S., Prasad, B.L.V., Patole, M.S., Sastry, M. and Schouche, Y.S., 2008. Extracellular synthesis of crystalline silver nanoparticles and molecular evidence of silver resistance fromMorganella $s p$.: towards understanding biochemical synthesismechanism. Chem. Bio. Chem, 9, 1415-1422.

[5] Mandal, D., Bolander, M.E., and Mukhopadhyay, D., 2006. The use of microorganisms for the formation of metal nanoparticles and their application.Appl. Microbiol. Biotechnol, 69 (4) ,485-492.

[6] Zhang, X., Yan, S. andTyagi, R.D., 2011. Synthesis of nanoparticles bymicroorganisms and their application in enhancing microbiological reaction rates.Chemosphere,82 (3), 489-494.

[7] Kalishwaralal, K., Deepak, V., Pandian, S.R.K., Kottaisamy, M.,BarathM, S., Kartikeyan, B.and Gurunathan, S., 2010. Biosynthesis of silver and gold nanoparticles using Brevibacteriumcasei. Coll. Surf. B ,77,257-262.

[8] Kalimuthu, K., Babu, R.S., Venkataraman, D., Bilal, M.and Gurunathan, S., 2008. Biosynthesis of silver nanocrystals by Bacillus licheniformis. Coll. Surf B, 65,150-153.

[9]Maduabuchi, E. K.,Noundou, X. S.,Ejike, U. S. and Atuzie, W .,2018. Biosynthesis, Characterization and Antimicrobial Activity of Silver Nanoparticles Using Cell Free Lysate of Bacillus Subtilis: A Biotechnology Approach.American Journal of Nanoscience\& Nanotechnology Research, 6(1),18-27.

[10] Rajeshkumar, S. and Malarkodi,C.,2014. In vitro antibacterial activity and mechanism of silver nanoparticles against food borne pathogens Bioinorganic Chemistry and Applications. http://dx.doi.org/10.1155/2014/581890.

[11]Mugg, P., Seymour ,S. and Clark, S., 2013.Anewmethod for the identification of Bacillus spp., and related species involved in food poisoning and spoilage.MicrogenBioproductsLtd,Camberley ,Surre,UK.

[12] Ekhaise,F .O. and Nkwelle, J.2011 .Microbiological And Physicochemical Analyses Of Oil Contaminated Soil From MajorMotor Mechanic Workshops In Benin City Metropolis,Edo State, Nigeria.J. Appl. Sci. Environ, 15 (4), 597-600.

[13]Vithiya,K., Rajendran, K.and Shampa, S.2014. Bacillus spp. Mediated Extracellular Synthesis of Silver Nanoparticles. Int. J. Pharm. and Pharm.Sci, 6(2),82-88.

[14]Dilmi, F.,Chibani,A. and Rezkallah, K .S.,2017.Isolation and molecular identification of hydrocarbon degrading bacteria from oil contaminated soil.International andjournal of bioscience,11(4),272-283.

[15]Mukherjee ,K., Gupta ,R., Kumar ,G., Kumari,S., Biswas,S.,Padmanabhan,P.2018.

Synthesis of silver nanoparticles byBacillus clausii and computationalprofiling of nitrate reductase enzyme involved in production.Journal of Genetic Engineering and Biotechnology, 16,527-536.

[16] Grazyna,A. P ., Joanna, C., Barbara ,M., Barbara ,T., Libor, K.,Ales ,P., Robert, P., Radek, Z., Katarzyna,P. andPrzemysław, B., 2015.Synthesis of silver nanoparticles by Bacillus subtilis T-1 growing on agro-industrial wastes and producing bio surfactant. The Institution of Engineering and Technology, 1-7.

[17] Saravanan, M.,Davoodbasha, M. A.,Prakash, P.andPugazhendhi, A., 2018. Synthesis of silver nanoparticles from Bacillus brevis (NCIM 2533) and their antibacterial activity against pathogenic bacteria.Microbial Pathogenesis,(116),221-226.

[18]Wang, C., Kim,Y. J., Singh ,P., Mathiyalagan, R., Jin, Y.andYang,D. C.,2015.Green synthesis of silver nanoparticles by Bacillus methylotrophicus, and their antimicrobial activity. Artificial Cells, Nanomedicin, and Biotechnology, 1-6.

[19]Silambarasan, S. and Abraham,J.,2012.Biosynthesis of silver nanoparticles using the bacteria Bacillus cereus andtheir antimicrobial property.Int J Pharm PharmSci, 4( 1), 536-540.

[20]Maduabuchi, E. K., Noundou,X .S ., Ejike, U. S. and Atuzie, W., 2018. Biosynthesis, Characterization and Antimicrobial Activity of Silver Nanoparticles Using Cell Free Lysate of Bacillus Subtilis: A Biotechnology ApproachAmerican Journal of Nanoscience\& Nanotechnology Research, 6,18-27.

[21]Safuddin,N., Wong, C.W. and Yasumira, N. A .A., 2009. Rapid biosynthesis of silver nanoparticles using culture supernatant of bacteria with Microwave irradiation . E-Journal of chemistry,6(1),61-70. 
[22] El- Shanshoury, A.R., Elsilk, S. E .and Ebeid, M. E., 2011. Extracellular biosynthesis of silver nanoparticles using Esherichia coli ATCC 8739 Bacillus subtilis ATCC6633 and Streptococcus thermophilesESh1 and Their Antimicrobial Activities .International Scholarly Research Nanotechnology ISRN,1-7.

[23]Dahikar, S. B. and Bhutada ,S.A.,2013 .Biosynthesis of silver nanoparticles using bacillus megaterium and their antibacterial potential. IJADD,3 (1), 13 -19.

[24]Singh,N.,Saha, P.,Rajkumar,K. andAbraham, J.,2014. Biosynthesis of silver and selenium nanoparticles by Bacillus sp. JAPSK2 andevaluation of antimicrobial activity.Der Pharmacia Lettre,6 (1),175-181. 